\title{
EVALUATION OF SOCIAL MEDIA INFLUENCE IN THE FIGHT AGAINST CORRUPTION IN NIGERIA
}

\author{
Chiemezie Chukwuka Ugochukwu \\ Department of Mass Communication \\ Nnamadi Azikiwe University, Awka \\ ugochukwuchiemezie@gmail.com
}

\begin{abstract}
The 2019 corruption perception index report attest to the fact that corruption is on the increase in Nigeria. With the level of widespread corruption in Nigeria, it needs to be tackled for the country to remain relevant among countries of the world. This work is structured to examine how social media have helped in the fight against corruption. The internet has helped the growth of social media in Nigeria because with Smartphone's and handheld devices, one can easily connect to the social media platform. Technology determinism theory and Agenda-setting theory of communication were used for the study. Library research method was adopted for the study and relevant information about corruption and social media from journals, newspapers and books were analyzed. This study concludes among others that social media are effective in the fight against corruption. It exposes corrupt practices and persons and ensures that persons indicted are prosecuted. The study recommends, among others that government should effectively use social media handles and encourage whistle blowing to help fight corruption in Nigeria.
\end{abstract}

Keywords: Evaluation, Social Media, Corruption, Fight, Nigeria

\section{INTRODUCTION}

The fight against corruption in Nigeria has been a difficult task for the government and citizens of Nigeria. There are many suggestions, publications and methods drafted to fight the hydra-headed monster, but none has achieved a giant stride towards the fight against corruption. Odekunle, (2007) in Moyosore, (2015) is of the view that every effort evolved at addressing the scourge has always been frustrated by the evolution of even more effective and sophisticated methods of corruption. At the virtual conference of Independent Corrupt Practices and other related Offences Commission (ICPC) on corruption, the Vice President Yemi Osinbajo said the fight against corruption is getting difficult daily and many will be discouraged in standing up against fraud (Adetayo, 2020). Corruption crime is a dishonest attitude carried out by persons and institutions with institutionalized authority to acquire illicit funds and properties for private use. Corruption has destroyed the entire Nigerian society (Uzochukwu, Ekwugha \& Ukwueze 2014, p.7) and efforts aimed at reducing fraud in this society have not yielded much result. Corruption thrives in Nigeria and individuals severely affected by it are not willing to speak up or resist the practice of corruption. Bribery denies human beings maximum security, good education, health, roads and many other basic needs that human beings may require in their day to day activities (Ahmad, 2018).

In Nigeria, corruption exists in various forms like ghost workers syndrome, the slow movement of files, inflation of contracts fees, extortion by police officers, port congestion, improper issuance of a license to import goods, looting of public funds by politicians among others (Uzochukwu et al. 2014 p.6). Although, the government of Nigeria claimed that it had channelled enormous financial and human resources towards the fight against corruption, the global rating of Nigeria as regards corruption leaves more questions than answers to the government. In 2019, the Transparency International Corruption Perception Index showed that Nigeria scored 26 out of 100 points falling by one point in 2018 and ranks 146 out of 180 
countries (Premiumtimesng.com, 2020). This ranking by Transparency International is the fact that no Nigerian can dispute considering the level of infrastructural decay. However, the level of Foreign Direct Investment (FDI) by international businesses will be low due to increasing corruption in Nigeria. In arriving at the parameters for scoring Nigeria low in corruption index, Transparency International listed several factors that include (a)The Nigeria rule of law is selective- the rich and powerful do not play by the rules. (b) Backlash against media and civil society damages Nigeria anti-corruption effort. (c) Institutionalized corruption in political parties and political integrity. (d) Poor understanding of the definition of corruption and how to tackle it. (e) Anti-corruption legal and policy framework is underdeveloped. (f) Inability to implement recommendations on anti-corruption. (g) Corruption in vital sectors such as oil and gas is endemic (Premiumtimesng.com 2020). These listed factors are the reason corruption thrives in Nigeria and an effort to tackle it remains impossible. Moyosore, (2015) in his study, listed six factors that encourage corruption in Nigeria to include: (a) Weak institutions of government and a culture of getting fatty syndrome by public officials. (b) The Lukewarm attitude of the enforcers of the law. (c) Cultural and Institutional factors. (d) Weak reward system and low remuneration for public servants. (d) Bureaucratic bottlenecks in government agencies. (e) Absence of transparent financial institutions.

The emergence of new media (Social Media) in the $21^{\text {st }}$ century became a beacon of hope towards the fight against corruption. Communication is at the centre of human development because issues and events that shape the society revolve around communication. Social media are novel communication tool that enhances message distribution to many people with the aid of the internet. To this effect, Nwabueze (2009) cited in Nwabueze (2014, p.165) affirms that the new media make more information available to an average internet user and also have more capacity to contain details of a story than any other medium. Social media has grown over the years, and features which aid social media users have witnessed rapid modifications and improvements to ensure user-friendly platform. Benefits derived from social media are many hence many regard it as a powerful tool to help combat corruption in our society. Kaplan and Haenlin (2010) in Nwabueze (2014, p.170) defines the social media as media that use web-based technologies to transform and broadcast media monologues into social media dialogues. An issue discussed at personal level becomes a public matter when analyzed on social media. Dominick (2013, P.24) defined social media as online communication that use special techniques that involve participation, conversation, sharing, collaboration and linkage. Two social media platforms namely Facebook and Whatsapp are believed to be familiar and widely used in Nigeria. Facebook social media platform allows users who are registered to create profiles, upload videos and pictures about themselves and happenings in their immediate environment, especially as regards corruption. On the other hand, Whatsapp social media platform can share messages with groups and individuals on the platform. These two social media platforms are installed from Google play store or apple store on internetenabled phone or handheld devices.

In the light of the above, this study seeks to evaluate social media influence in the fight against corruption considering the number of people who are active users in Nigeria that run in millions (Akinpelu, 2020). Countries around the globe have adopted the use of social media in governance, which sees many agencies having their social media handle or names for ease of administration and broader coverage. 
The problem; however is to evaluate how the social media have helped in the fight against corruption in Nigeria. The 2019 Corruption Perception Index by Transparency International in 2019 ranked Nigeria 146 out of 180 countries analyzed. This rating is a sad development to the socio-economic advancement of Nigeria as foreign investors, and highly quoted companies would not want to invest and do business in Nigeria. Corruption has destroyed the entire system of governance in Nigeria (Okolo \& Akpokighe, 2014), and this makes it difficult to fight and reduce crime to the barest minimum. Prof. Patrick Lumumba a frontline fighter against corruption in Africa said: "the African Continent has lagged in most facets of human development and its largest country; Nigeria has remained in poverty due to fraudulent activities in public service" (Ogundipe, 2016). Internationally, Nigeria is a laughing stock because no country takes them seriously because of weak institutions caused by corruption.

Social media is fundamental in the fight against corruption in Nigeria. On April 18; 2020, a lady flogged by policemen in Iwo Osun state went viral on social media. Police officers flogged the Lady Tola Azeez for violating lockdown in Iwo, and the video of the assault went viral on the twitter account of Ruggedman which drew the attention of police authorities after the woman retweeted the video, the Police Commissioner in the state announced the arrest of the officers and subjected them to orderly room trial where they were found guilty and dismissed from Nigeria Police Force (Olabiyi, 2020). Social media is doing its part in curbing the increasing terrorism in the Northern part of Nigeria where Bokoharam elements have destroyed the socio-economic activities of that region. April $14^{\text {th }} 2014$, Bokoharam terrorists attacked Government Secondary School Chibok, Borno State and kidnapped 276 school girls. It sparked outrage nationally and globally and led the social media community to launch Hashtag (\#BringBackourGirls) to draw the attention of the government and international community. The \#BringBackourGirls group was championed by Dr Oby Ezekwesili with other eminent Nigerians to seek the release of the girls. Driving philosophy of the group is 'a diverse group of citizens advocating for speedy and effective search and rescue of all our abducted girls and a rapid containment and quelling of insurgency in Nigeria' (bringbackourgirls.ng). The group brought Nigeria to the limelight, which made the International community to provide material and human resources to help fight terrorism. The \#BringBackourGirls campaign led to the establishment of a Safe School Initiative and a 20 million dollar fund championed by Former British Prime Minister Gordon Brown aimed at protecting schools in the troubled region (Ogunlesi, 2014).

This is an indication that social media have the capacity to change certain ills in our country when properly deployed and benefits derived from its use are numerous.

\section{THEORETICAL FRAMEWORK}

This work is hinged on Technological Determinism and Agenda-setting theories of communication. Marshal McLuhan propounded Technological Determinism theory in 1964. The position of the argument is that technology has altered the way the media audience reacts to messages or communication from an electronic medium. This theory explains the role of technology in shaping cultural orientation, values and events in the larger society. The proponents of technological determinism argue that society is influenced and shaped by technological development (Hauer, 2017). Social media is driven by the internet across the countries of the world, and it is a valuable tool that will revolutionalize the globe. Similarly, McQuail (2005, p.104) cited in (Nwabueze, 2014 p.56) states the basic tenets of technological determinism theory: (i) communication theory is fundamental to society 
each technology has a bias to particular communication forms (iii) the sequence of invention and application of communication technology influences social change (iv) communication revolutions lead to social revolutions.

Agenda setting theory of communication was propounded by Maxwell Mac Combs and Donald Shaw in 1968. This theory of communication views the media (social media inclusive) as having the capacity to set agenda for the media audience on what to think by continually repeating news and events thereby placing importance on such stories. When users of social media platforms like Facebook, Whatsapp, among others share stories, pictures and videos about corruption on a day to day format, importance are placed on such stories. The position of social media users about crime is as a result of what the platform has mirrored to them. Daily upload of stories and videos about corruption sets agenda for the public because social media stories that are topical go viral. The mass media move issues from press agenda to public programme. (Nwabueze, 2014 p.44).

\section{LITERATURE REVIEW}

\section{CORRUPTION IN NIGERIA: HYDRA HEADED MONSTER}

In 1999 Nigeria returned to democracy after years of military draconian rulership, there was hope that myriads of the problem confronting Nigeria especially corruption be reduced thereby launched Nigeria as the fastest growing economy in Africa. Twenty years after Nigeria adopted a democratic system of governance, fraud is on the increase destroying the fabrics of the entire country and reducing our international standing among Nations of the world. Akanbi, (2003) in Iyanda, (2012) listed the levels of corruption: (a) Street level of corruption which describes corruption in administration as day experiences of the citizens in their interactions with officials. (b) Business corruption that occurs among low to mediumsized business with connivance with public sector officials. (c) High level of corruption which involves vast sums of money in high power centres in finance, public service and administration. Democracy that ought to have been progress to Nigeria turned out to fuel the fire of corruption which made Okunola, et al (2019) to say that with the advent of democratic rule in 1999, the link between fraud and democratic governance had become stiff. These include electoral malpractice, lack of intra-party democracy, grand corruption, impunity and reckless over- ambition of political elites among others. This is an indication that the return of democracy to Nigeria has done little or nothing to curb corruption. Ubi \& Eko (2012) highlight that 'according to Ribadu, Nigeria's previous leaders stole about 64 trillion (about US $\$ 507$ Billion) from public coffers. This, when benchmarked against the 2008 budget of \#2.456 trillion nairas and 2011 budget of \#4.972 trillion nairas, this translate to 26 years and 12 years budget respectively.

Various looting by past governments (Military \& Democratic Governments) informed the decision by Obasanjo's government to establish Economic and Financial Crime Commission (EFCC) and Independent Corrupt Practices and Other Related Offences (ICPC). Concurring to this, Moyosore (2015) avers that the unpalatable situation of corruption in Nigeria made the former President Obasanjo establish EFCC and ICPC. In Nigeria, corruption has led to wrong people occupying political offices, and tremendous amount of money has been appropriated into private pockets, leaving mounting internal and external debts (Anthony \& Pre-Ebi, 2017). In Nigeria presently, enormous billions are leaving government treasury unaccounted for. Salawu, (2007) in Moyosore (2015) said that Thisday Newspaper reported that the level of leakages in Nigeria has attracted an annual rate of $\$ 25.76$ billion loss to 
fraud-related crimes in the last five years and that on daily basis too; the country is losing about $\$ 70,575,342$ to corruption and other related crimes.

No nation can progress in education, health, the economy with this level of stealing of our shared heritage by few people in government. This level of stealing is the reason all sectors of the Nigerian economy are in a state of collapse. Different segments of the Nigerian economy are on their knees because of corruption. The education sector is profoundly affected by fraud, and 'Transparency International said that 66 per cent of the money Nigerian government allocates to education is stolen by corrupt officials' (Adegboyega, 2019). Across the globe, countries are ensuring that education remains the pivotal engine that drives other sectors by allocating vast sums of money to stay competitive and provide solutions to societal problems. Corruption in the education sector of Nigeria has contributed to the decline of universities ranking globally, no university make the list of first to one thousand best universities. Katharina, (2004) in Nwankwo \& Nweke (2016) opines that corruption thrives in the education sector due to the following factors: (a) inadequate legal framework to prevent and fight fraud. (b) Responsibilities, decision making structures and procedures at Federal, State and Local levels are complex. (c) Absence of independent supervision, (d) Inadequate documentation, (e) Non-disclosure of information to students and limited understanding of procedures and decisions. (F) Inadequate expertise. The idea of global ranking of universities has become a veritable means by which we assess the performance of various universities across the continent (Olaopa, 2016).

The health sector in Nigeria is in a sorry state, from poorly funded hospitals; to poorly paid health personnel to reduced supply of drugs at an affordable rate the list is endless. Husmann (2011) in Elekwachi, (2019) insists that corruption in the industry has manifested in ineffectiveness, reduced quality services, poor hospital maintenance. This has increased medical tourism in Nigeria as people, government officials among, others, travel to seek better medical care lacking in Nigeria. A Nation without a healthy and tasty medical facility cannot flourish. Nigeria's overall health system performance was ranked $187^{\text {th }}$ position among the 191 member states of the World Health Organization in 2000 (Efe, 2013). In 2019, WHO highlighted that Nigeria health system is deficient in areas like poor funding, brain drain, inadequate infrastructure, disease outbreak management among others (Muanya \& Onyenucheya, 2019). Such ranking from a reputable organization like the World Health Organization (WHO) can trigger anger, hopelessness and frustration in the common man, who cannot afford medical treatment outside the shores of Nigeria. Rotimi (2015) in his work about corruption in health sector notes that 'effectively US $\$ 2.2$ million had been misused by Nigerian officials and has to be refunded by the Nigerian government, shameful as this is the lack of conscience of officials who have misappropriated funds meant to save lives'.

The aviation sector of the Nigerian economy was the pride of African Airways, but has been destroyed by corruption (Ibekwe, 2018; Oghojafor \& Alaneme, 2014). Nigerian Airways, founded in 1958 was a bride for many travellers across the world and Nigeria in particular because the quality of service was top notch. After years of operation, Nigerian Airways became a shadow of its self. In 2003 when the airline ceased operations, revelations about the activities were mind-blowing. To this, (Ibekwe, 2018) wrote that former President Olusegun Obasanjo in 2002 set up the Justice Obiora Nwazota Judicial Commission to probe the operations of Nigerian Airways. The commission revealed the looting and misappropriation of the company's resources to the tune of 60 billion naira. 
Crude oil became the significant earning of Nigeria at the International Market where Nigeria has received billions of naira since the discovery. Major International Oil companies have their operational base in Niger Delta region of the country. Yet the area is suffering from environmental degradation and poor standard of living caused by corruption. Moyosore (2015) opines that different forms of corruption have gulped most of the national earnings, particularly from the oil sector since independence.

The level of infrastructural decay across different sectors of the economy is deeply caused by corruption. From roads, electricity, water supply, among others poorly built and the ones appropriately done are not maintained. The infrastructure of any country is directly connected with the quality of life (Anthony \& Pre-Ebi, 2017).

\section{THE ADVENT OF SOCIAL MEDIA IN NIGERIA}

In 2001, the Federal Government of Nigeria under the leadership of Olusegun Obasanjo licensed the operations of telecommunication industry in Nigeria which was a springboard for social media in Nigeria. The gap in communication from a person to another irrespective of the location was closed. Information and Communication Technologies (ICTs), which drive the social media in Nigeria, witnessed a big boom as many institutions, government agencies, banks among others relied on ICT for their day to day activities. Agreeing to this (Nwabueze, 2014, p.3) said the advent of Information and Communication Technologies (ICTs) such as computers, digital broadcasting, satellite and cable television, the Internet and World Wide Web (www) has contributed immensely in ensuring the sophistication of the communication process and also bridging the gap between the sender and the receiver. The internet has grown in Nigeria and it has helped to strengthen the various social media platforms in Nigeria like Facebook, Instagram, Twitter, Whatsapp, among others. Events and happenings around the globe can be accessed by handheld devices, computers, and sophisticated phones reinforcing the earlier prediction of Marshal McLuhan's concept of a global village.

Social media have become popular among Nigerians (Adults, Youths and Teenagers) and registration for membership is free with phones, computers and handheld devices that can access the internet. A Nigerian has at least an account in any of these social networking sites (Alade, 2017).With the level of social media users; information sharing especially as it concerns Nigerians is expected to be high.

Social media platforms like Facebook, Whatsapp, Twitter, Instagram among others have seen Nigeria as a fertile ground to boom and expand their business and Nigeria is a country rich in human and material resources with a huge population. In 2019, there were 98.39 million active users compared to 2018 when the figure was 94 million active users of the internet (Udodiong, 2019). Going with the figure, internet usage and penetration is high; hence social media use in Nigeria is increasing. Nigeria already has one of the continent's highest Smartphone penetration rates and that number will get even higher as Smartphone subscription is expected to be on the increase Kazeem, (2016).

However, there have been growing concerns about the negative impact of social media in our society due to its unique features that is different from traditional media like newspaper, radio and television. Biswas, Ingle \& Roy (2014) listed the negative impact of social media to include: it cannot be entirely controlled, social media is prone to hacking, responses from social media sites can lead to a backlash, negative sentiments can influence electioneering, and there are misrepresentations of facts in social media. Hyacinth \& Barigbon (2014) 
believes that misinformation or rumours can quickly spread on social media and may allow criminals to keep track of police activity. Chinedu Okeke \& Obi (2016) gave the negative aspect of social media as : disseminating unfiltered/unverified information, hate messages and rumours, increased piracy, immoral conduct and lurid sex photo, the anonymity of sources, images and sounds digitally manipulated, addictive nature of social media and bullying and digital offensive dialogues. The Social media industry is an industry with weak regulations, and these make users flood the social media with contents not minding the implication it could cause. Youths are exposed to social vices, and many addicted to it and abandon other important aspects of their lives (Olowe, 2018). In July, 2012 a post-graduate student of Nassarawa State University was murdered by friends she met on Facebook which sparked condemnations across Nigeria. Cynthia died after she and her once virtual friends needed to see flesh and blood, following some periods of chatting on Facebook and her death was not only condemned by the generality of Nigerian populace but had government contemplating slamming legislation that would check the excesses of internet users (Hyacinth \& Barigbon, 2014). Most users of the Social media indulge in harmful vices, and this is not good for Nigeria because there are numerous benefits to be derived from the Internet and social media.

\section{SOCIAL MEDIA AND ITS IMPACT IN THE FIGHT AGAINST CORRUPTION}

The critical role social media play in Nigeria has led to awareness, engagement and reaching out to the global community on issues that have destroyed Nigeria and project us to the world in a bad light. From HASHTAG like \#EndSARS and various campaigns against corruption and other ills going on in Nigeria, it has brought the attention of government and the world. In the words of (Asika, 2016), social media allows this vast melting pot of Nigerians to express themselves in many ways from memes, to blogs, videos to social media posts from public commentators to private citizens, everybody has a voice, but however, of course many still need help to shape that voice and to learn how best to bring it to their audience.

Social media platforms in Nigeria like Facebook and Whatsapp have witnessed institutions, groups and associations owing a webpage on these platforms and members of the various platforms utilize these platforms to share stories, report events and most importunately expose the corruption that has damaged the Nigerian society. In 2017, a group of Nigerians took to their social media platforms. It started a campaign of \#ENDSARS to tell Nigerians and the world that a department of Nigeria Police charged with the protection of lives and properties are indulging in extrajudicial killings and harassing the citizens they ought to protect. The protest carried out online and in some states in Nigeria drew the attention of the Federal Government and Nigeria. The then Acting President, Prof. Yemi Osibanjo called for an immediate overhaul of SARS and Nigerians rejoiced because their voices have been heard and something was going be done (Bwala, 2019). This indicates that social media effects change in Nigerian society by beaming its searchlight on institution and government authorities.

Communication and media scholars have referred to social media as the fifth estate of the realm because it reaches millions of users globally with the help of Internet. In the words of (Nwabueze 2014, p.176), " the fifth estate of the realm is a concept used to recognize the emerging socio-political significance of the social media in the modern world as powerful tools of communication, sensitization, awareness creation, contributing immensely in shaping the nature of governance in any society". In Nigeria, the level of poverty, unemployment and lack of social amenities are caused by years of corruption leaving the people with no option 
than to survive amid, nothing thereby resulting to social unrest and social activism. Social activism is the use of various social media platforms to organize protests, rallies to enforce change in the society. With the new trend of organizing protest online with Hashtags (\#) symbols as the registration logo, people in their hundreds sometimes thousands identify with social activism. In line with this, (Nwabueze 2014, p.178) views social media activism as the use of social media to mobilize people for a social course.

In 2012, Nigeria witnessed a massive social protest organized by labour unions and civil societies that brought the country to a halt. The rally saw the emergence of '\#OccupyNigeria' were drawn from social media platforms like Facebook, twitter, blogs and the protest was characterized by strikes and rallies (Hari, 2014). The protesters were angry that the Federal Government led by Dr Goodluck Jonathan announced the increase in the pump price of Premium Motor Spirit (PMS) from \#65 to \#141 based on the removal of fuel subsidy. Social media platforms played a significant role in organizing and expanding awareness among the general public and perhaps stimulating and facilitating discussions on issues beyond fuel subsidy removal to include broader issues of corruption and accountability in the governance of the country (Hari, 2014). The Government of President Dr Goodluck Jonathan was forced to drop removing fuel subsidy as protests were increasing hence the need to maintain law and order.

The fact that our education sector in Nigeria is bedridden with corruption leaves no one in doubt because our government failed to address issues facing the industry. However, social media has done a lot in exposing the rot in our universities by posts, pictures and videos where users upload and share. The issue of sex for mark in many universities in Nigeria projects our citadel of learning as shameful and unfortunate. In 2018, a recorded audio conversation between a senior lecturer in the Department of Accounting at the Obafemi Awolowo University, Ile Ife, Professor Richard Akindele negotiating sex for marks with one Monica Osetoba Osagie an MSc student in Business Administration went viral on the traditional and social media (Usman, 2018). When social media platforms helped to circulate the case of Monica, it forced the authorities of OAU to set up a panel to look into the allegation, and institutions like Independent Corrupt Practices and other Related Offences Commission (ICPC) and some NGO's came to Monica's rescue. Justice Onyetenu sentenced Prof. Akindele to 24 months imprisonment for asking Monica sexual gratification to pass her (Hanafi, 2020). One cannot dispute the fact that social media is a powerful tool if properly used.

\section{CONCLUSION}

The fact that social media are tools that help in the fight against corruption is not in doubt. Through the conceptual and empirical review from journals, newspapers and books, the study concludes that if social media is deployed rightly in the fight against corruption, it will awaken authorities to their responsibility. The internet is also helping much the growth of social media greatly as features of different social media platforms are built around it. This study harps on the need for Nigerians to adopt social media to expose corrupt practices and persons. 


\section{RECOMMENDATIONS}

- Government agencies like EFCC \& ICPC should adopt strategies for people to report corrupt practices through social media.

- Agencies of Government should be mandated to have at least one active social media handle where people report corrupt practices.

- Nigerians should be bold enough to report corrupt practices through their social media platforms.

\section{REFERENCES}

Adegboyega, A. (2019). More than half of Nigeria's education budget lost to corruption. http://premiumtimesng.com/news/topnews. May 5th, 2020.

Adetayo, O. (2020). Soon, many will be discouraged to stand up against corruptionOsibanjo. http:punchng.com. July $14^{\text {th }}, 2020$.

Ahmad, H. (2018). EFCC and the fight against corruption. http://guardian.ng. May $15^{\text {th }}, 2020$.

Akinpelu, O. (2020). $60 \%$ of Nigerians are still not connected to the internet and only $10 \%$ Are active on social. http://technext.ng|2020. April 19 ${ }^{\text {th }}, 2020$.

Alade,A.M.( 2017). The social media and the Nigerian society. http://www.academia.edu. April $23^{\text {rd }}, 2020$.

Anthony, R.\& Pre-ebi, B. (2017). Critical infrastructure decay and development crises in Nigeria.Global Journal of Human Social Science. http://globaljournals.org. On May $13^{\text {th }}, 2020$.

Asika, O. (2016). A reflection on social and its impact on Nigeria. http://guardian.ng. May $10^{\text {th }}, 2020$.

Barigbon, G.N.\& Hyacinth, C.O. (2014). Social media as a bastion for correcting moral ills in Nigeria: A focus on Educational Decadence. http://iiste.org. May 2 ${ }^{\text {nd }}, 2020$.

Biswas, A.,Ingle, N.\&Roy, M.(2014). Influence of social media on voting behavior. Journal of Politics\& Governance. http://jppgnet.com. $26^{\text {th }}$ May, 2020.

Bwala, N. (2019). Rant here: End SARS campaign. http://punchng.com. May 15th, 2020.

Chinedu Okeke, F. C. \& Obi, I. (2016). Social Media as a: Political Platform in Nigeria: A focusn on electorates in South-Eastern, Nigeria. Journal of Humanities and Social Science. http://iosrjournals.org. May $13^{\text {th }}, 2020$.

Dominick, J.R. (2013). The dynamics of mass communication: media in transition,NewYork :McGrawHill.

Efe, I.S. (2013). Healthcare problem and management in Nigeria. http://academicjournals.org. May $18^{\text {th }}, 2020$. 
Elekwachi, P.N. (2019). Perceptions of financial bribery and kickbacks on Nigeria healthcare public policy. http://scholarworks.waldenu/dissertations. May $19^{\text {th }}, 2020$.

Hari, S.I. (2014). The evolution of social protest in Nigeria: the role of social media in the 'occupy Nigeria' protest. International Journal of Humanities and Social Invention Vol.3 Issue 9. http://ijhssi.org. April 25 $5^{\text {th }}, 2020$.

Hanafi, A.(2020). OAU sex-for-mark lecturer released from prison two years after. http://punchng.com. May $19^{\text {th }}, 2020$.

Hauer, T. (2017). Technological determinism and new media. http://ijels.com. May $10^{\text {th }}$ 2020.

Ibekwe, N. (2018). Special Report: The men who embezzled Nigerian Airways to death. http://premiumtimesng.com/news. April $17^{\text {th }}, 2020$.

Iyanda, D.O. (2012). Corruption: definitions, theories and concepts. Arabian Journal of Business and Management Review. Vol.2 No.4. http://arabianjbmr.com. May $27^{\text {th }}, 2020$.

Kazeem, Y. (2016). More people use facebook in Nigeria than anywhere else in Africa. http://qz.com. April $23^{\text {rd }}, 2020$.

Moyosore, S.O. (2015). Corruption in Nigeria: Causes, Effects and Probable solutions. Journal of Political Science \& Leadership Research.ISSN2504-883X Vol. 1 No.8.http://iiardpub.org. May $26^{\text {th }}, 2020$.

Muanya, C. \&Onyenucheya, A. (2019). Nigeria's health sector performance trailed behind other countries in 2019. https://guardian.ng/features/health. July 14,2020.

Nwabueze, C.D. (2014). Introduction to mass communication. Media ecology in the global village.Owerri: Topshelve Publishers.

Nwankwo, B.C. \&Nweke, P.O. (2016). Effects of corruption on educational system: A focus on private secondary schools in Nsukka zone. Global Journal of Human Science Vol.XVI Version 1. http://globaljournals.org. May 27 $7^{\text {th }}, 2020$.

Ogundipe, S. (2016). Africa remains poor because of Nigeria, ex-Kenyan anti-corruption chief.http://premiumtimesng.com. May $18^{\text {th }}, 2020$.

Ogunlesi, T. (2014). Hijacking Nigeria's \#BringBackOurGirls Campaign, why does West assume a tweet can fix Africa's problems. http://alijazerra.com. May $13^{\text {th }}, 2020$.

Oghojafor, B.\& Alaneme,G.(2014). Nigeria Airways: the grace and grass experience.

International Journal of Business \&Social Science.Vol.5No.13. http://ijbssnet.com. April $24^{\text {th }}, 2020$. 
Okolo, P.O. \& Akpokighe, R. (2014). Corruption in Nigeria: The possible way out. Global Journal of Human Science:Political Science. Vol.14 issue 7. http://globaljournals.org/GJHSS. April 17th,2020.

Okunola, M.O., Umaru A. \& Inusa,S.H. (2019). Manifestation and impacts of corruption on democratic governance in Nigeria. International Journal of Development and Management Review (INJODEMAR) Vol.14 No.1. http://ajol.info. April $16^{\text {th }}, 2020$.

Olabiyi, L. (2020). Untold stories of lockdown: How security agents extort Nigerians, spill blood. http://sunnewsonline.com/untold-story-of-lockdown. April 22, 2020.

Olaopa, (2016). Nigerian Universities: global ranking and critical reform issues. http://nationonlineng.net/nigerian-universities. April 20th, 2020.

Olowe, P. (2018). Influence of social media in Nigeria youths. http://thenationonlineng.net. $26^{\text {th }}$ May, 2020.

Rotimi, J. (2015). Corruption in the health sector. http://thenationonlineng.net. April $26^{\text {th }}$, 2020.

Ubi, P.S., Eko,S.A. \& Ndem,B.E.(2012). Corruption and its implication for actualizing Nigeria Vision 20-2020. Global Journal of Social Science .Vol11 No.1. http://dx.doi.org. April $15^{\text {th }}, 2020$.

Udodiong, I. (2019). Here is how Nigerians are using the internet in 2019. http://pulse.ng. $18^{\text {th }}$ April, 2020.

Uzochukwu, C.E., Ekwugha, U.P. \&Ukwueze,C.A. (2014). Harnessing social media tools in Fight against corruption in Nigeria: Challenges and Prospects. International Journal of Social Relevance \& Concern. Vol2 issue 11. http//ijournals.in. April 18 ${ }^{\text {th }}, 2020$. 